\title{
Elektromágneses gyorsítású fegyver demonstrációs modellje
}

A projekt célja kettős. Egyfelől egy kísérleti eszköz megépítésével jól megismerhetők az elektromágneses gyorsítású fegyverek tulajdonságai, előnyei, hátrányai és jelen technikai eszközök korlátai. Másfelől arra a tényre kívántunk rámutatni, hogy ilyen eszközt bárki építhet magának a kereskedelemben kapható kereskedelmi alkatrészek felhasználásával.

Napjainkban igen sok amatőr is készít olyan fegyvereket, amelyek a lövedéket nem a hagyományos kémiai energiafelszabadítás elvén gyorsítják fel, hanem elektromágnesek segítségével biztosítják a kezdősebességet. Eredményeiket széles körben [1,2] teszik publikussá az interneten [3,4].

Noha a cikkben bemutatott eszköz mért torkolati energiája alig haladja meg a $6,8 \mathrm{~J}$-t, így is komoly sérülést okozhat. Az alábbi tanulmány arra is rámutat, hogy hasonló módon, továbbra sem felhasználva különleges alkatrészeket, készíthető nagyobb, akár 10-20J torkolati energiájú fegyver is.

\section{A BERENDEZÉS ELVI ELEKTRONIKAI FELÉPITÉSE}

Elvileg az elektromágneses gyorsító egy rendkívül egyszerü szerkezet (1. ábra). A mágnesezhető lövedéket egy áram járta tekercs körül felépülő mágneses mező vonzza magához. A lövedék pályáját egy vékony falú vetőcső biztosítja.

A tekercs áramát úgy kell időzíteni, hogy a lövedék távozása során már ne legyen a tekercs körül mágneses mező, ami lassítaná azt. A tekercs által létrehozott mágneses in-

\section{1. ábra. Az elektromágneses gyorsító szerkezeti felépítése}

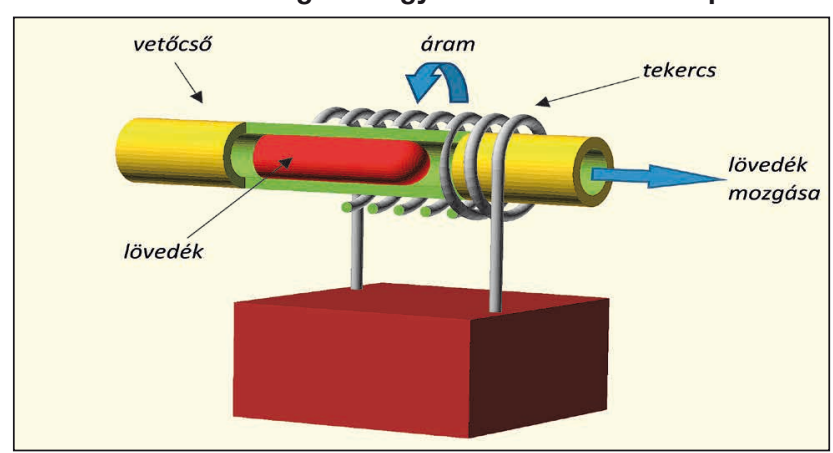

ÖSSZEFOGLALÁS: Napjainkban sokat lehet hallani olyan különleges fegyverekről, amelyek a lövedéket nem a hagyományos kémiai energiafelszabadítás elvén gyorsitják fel, hanem elektromágnesek segítségével biztosítják a kezdősebességet. Az angol terminológiában „coilgun” néven olvasható számos leírás ezekről az eszközökről.

KULCSSZAVAK: Elektromágneses gyorsítású fegyver, coilgun, modell, Óbudai Egyetem dukció nagysága arányos a tekercsen átfolyó áram erősségével (1), ami végső soron meghatározza a lövedékre ható gyorsító erőt. A tekercs (szolenoid) által keltett mágneses indukció „B” kiszámítására Maxwell IV. és Biot-Savart törvényei alapján az alábbi összefüggés alkalmazható (1).

$$
B=\mu_{0} \frac{l \cdot N}{l},
$$

ahol

$B$ a tekercs által létrehozott mágneses mező indukciójának nagysága [T];

I a tekercsben folyó áram erőssége $[\mathrm{A}]$;

$N$ a tekercs menetszáma [1];

$l$ a tekercs hossza [m];

$\mu_{0}$ a mágneses vákuumállandó $\left[4 \pi \cdot 10^{-6} \frac{\mathrm{Vs}}{\mathrm{Am}}\right]$.

A fentiek alapján a menetszám növelésével, illetve a tekercs hosszának csökkentésével is növekszik a mágneses indukció, de a rövid idejű impulzus előálítása ezen paraméterek éppen ellenkező irányú módosítását, azaz csökkentését igénylik. Ennek megfelelően a mágneses indukció növelésének alapvető módja a tekercsen áthaladó áram növelése.

Ahhoz, hogy minél nagyobb áram folyhasson a tekercsen, mindenekelőtt egy igen kis belső ellenállású áramforrásról kell táplálni. A kondenzátor erre a legalkalmasabb. Tehát a kilövő elektromos szempontból egy tekercsből és egy vele párhuzamosan kapcsolt kondenzátorból áll. Ahhoz, hogy megfelelő időtartamú áramipulzusunk legyen, a feltöltött kondenzátort elvileg nulla idő alatt (gyakorlatilag a lehető legrövidebb idő alatt) a tekercsre kell kapcsolni. Ekkor a kisülés során létrejövő impulzus hossza a kapacitás és induktivitás értékeitől függ (gyakorlati szempontból még figyelembe kell venni a zárt áramkör ohmikus ellenállását is). A jó hatásfokú kisütés érdekében mechanikus kapcsoló helyett valamilyen félvezető kapcsolóelemet célszerű alkalmazni. Igen elterjedt erre a célra a tirisztor. A méretezésnél figyelembe kell venni, hogy a kisülés során - igaz, hogy csak néhány milliszekundum ideig - több ezer (!) Amper áram folyik a tekercsen.

A 2. ábrán látható gyorsító működése a következő. A „C” kondenzátorokat egy külső áramforrással a gyorsító üzemi feszültségére töltjük. A töltő áramforrás teljesítménye (maximális árama) csupán a töltési időt befolyásolja, a kilövő

ABSTRACT: There has been much talk about out-of-the-common weapons that accelerate projectile not by means of traditional release of chemical energy but by the use of electromagnets to achieve muzzle velocity. Many articles deal with these weapons called coilgun in English terminology.

\footnotetext{
Dr. habil. Molnár András Óbudai Egyetem, Neumann János Informatikai Kar molnar@uni-obuda.hu. ORCID: 0000-0003-4330-6547
} 


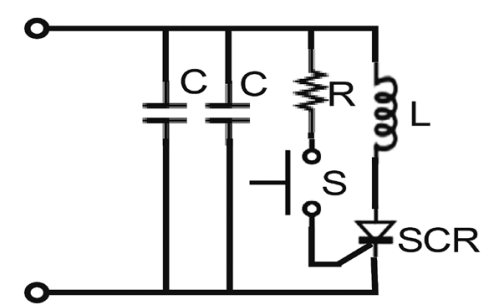

2. ábra. Az elektromágneses gyorsító elvi kapcsolási rajza

működésére egyébként nincs kihatással. Az „SCR” jelölésű tirisztor a töltés ideje alatt nem vezet, így az „L" jelü munkatekercsen nem folyik áram. A feltöltött kondenzátorok a tekercsen keresztül az „S” jelű pillanatkapcsoló megnyomásával sülnek ki. Ekkor történik meg a lövés. $A z$ „R” ellenállás, az alkalmazott tirisztor és a kondenzátorok maximális feszültségének ismeretében a szükséges nyitóáramot biztosítja. A tirisztor típusának megválasztásánál a rövid idejű áramot kell figyelembe venni, ami jelen esetben akár több ezer (!) Amper is lehet. A tirisztorok jellemzően akár egy nagyságrenddel nagyobb impulzus-áramot is képesek elviselni a statikusan megengedhető maximális áramhoz képest.

Amennyiben a gyorsító több fokozatot tartalmaz, azok a 2. ábrához hasonló szerkezetűek, de a tirisztor indítását nem nyomógomb, hanem valamilyen érzékelő jele végzi. A fokozat indításának legegyszerűbb módja egy optikai jeladó. Amikor a lövedék keresztezi a jeladó fényét, akkor a fotoérzékelő „árnyékba” kerül. Ezt a jelet kell a kapcsoló tirisztor vezérlőelektródájára kötni, ami indítja a hozzá kapcsolt fokozatot. A további fokozatok méretezésénél figyelembe kell venni a tekercshez közeledő lövedék sebességét. Általánosan elmondható, hogy minél gyorsabb a tekercsbe belépő lövedék, annál rövidebb impulzussal lehet gyorsítani. Ahhoz, hogy a gyorsítás hatásos legyen, a rövid impulzus nagyobb árammal kell, hogy párosuljon.

A 3. ábrán látható egy háromfokozatú elektromágneses gyorsító vázlatos felépítése. Az első fokozatot az előzőekben megismert módon, egy kapcsolóval lehet indítani. Ennek hatására a lövedék felgyorsul és a csőben, halad a második fokozat felé. A második fokozat előtt a vetőcső keresztül van fúrva, hogy a két furaton az alul elhelyezett fényforrás (a rajzon piros színű LED látható) fénye a felette elhelyezett fényérzékelőhöz (a rajzon kék színnel ábrázolt fotodióda látható) eljusson. Ezt a fényutat szakítja meg az odaérő lövedék. A fényút megszakadása által keletkezett elektromos impulzus indítja a hozzá kacsolt fokozatot, amely tovább gyorsítja a lövedéket. Az optikai jeladó távolsága az általa vezérelt tekercstől lényeges paraméter. A távolság meghatározásánál figyelembe kell venni az

\section{3. ábra. A háromfokozatú elektromágneses gyorsító vázlata}

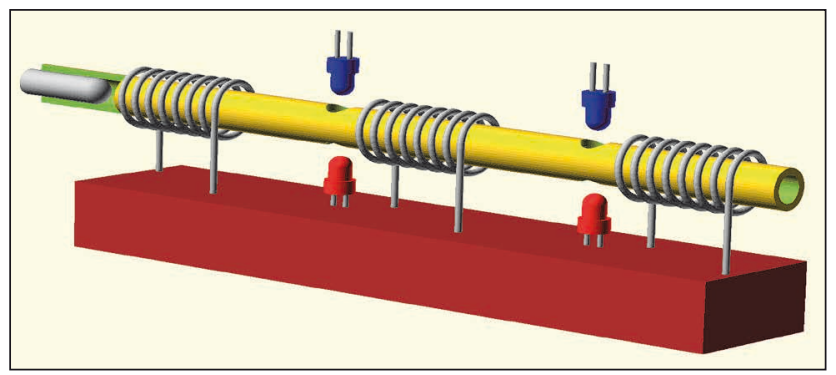

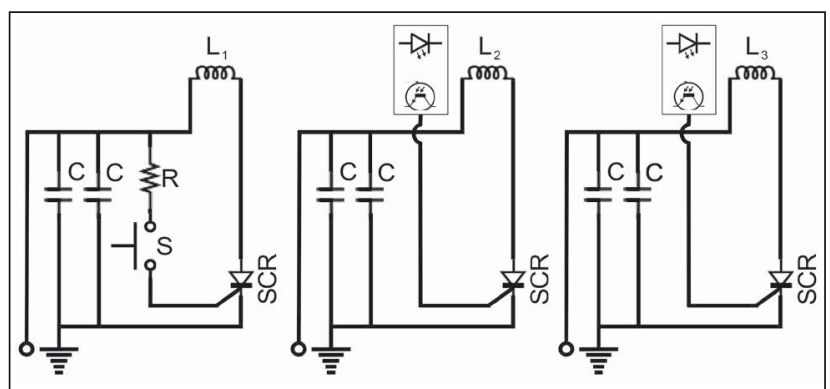

4. ábra. A háromfokozatú elektromágneses gyorsító elvi kapcsolási rajza

áramkör kapcsolási idejét és a lövedék belépési sebességét. Túl nagy távolság esetén a tekercs által keltett mágneses mező nem gyakorol megfelelő nagyságú gyorsító erőt a lövedékre. Túl közeli esetben előfordulhat, hogy még folyik áram a tekercsen, amikor a lövedék már távolodik tőle, de a még meg nem szűnt mágneses mező fékező hatást fog gyakorolni. A harmadik fokozat müködése megegyezik az imént leírt második fokozat működésével.

A 4. ábra szemlélteti a háromfokozatú gyorsító elvi kapcsolását. A rendszer gyakorlatilag három önálló egységből áll. Az egységeknek csak a földpontjuk közös, ami a hozzákapcsolt mérőkészülékek (a rajzon nem látható) egyszerűbb bekötését biztosítja. Minden egység saját kondenzátorteleppel és azokat függetlenül töltő egységekkel (a rajzon nem látható) rendelkezik. A független töltés lehetővé teszi, hogy a töltőáramkör ne terhelődjön túl a kisütött kondenzátorok egyidejű töltésétől. A gyakorlati megvalósítás során a kondenzátorok töltéséhez a fényképezéshez használatos villanólápák (vaku) töltő áramköreit használtuk fel. Ezeket az áramköröket úgy alakítottuk ki, hogy a hozzájuk kapcsolt kondenzátor töltését követő kisütés tranziens hatásaitól is védettek, így erre alkalmazásuk során külön figyelmet már nem kell fordítani.

\section{A beRENDEZÉS ELEKTRODINAMIKAI ÉS KINEMATIKAI SZIMULÁCIÓJA}

A lövedék gyorsítása számos tényezőtől függ. Egy viszonylag hatékony berendezés elkészítéséhez célszerű számításokat végezni az alkalmazásra kerülő energiatárolók (kondenzátorok), gyorsító elektromágnesek (tekercsek), a tápfeszültség, a lövedék mérete és más eszközök paramétereinek meghatározása érdekében. Mivel a számítások meglehetősen összetettek és sok változó együttes hatása befolyásolja a végeredményt, ezért érdemes szimulációs eszközt igénybe venni. A projekt során egy ingyenesen elérhető program eredményei alapján terveztük meg a megvalósításra kerülő eszközt [5]. A szimulátor több „klasszikus" számítási modullal és egy speciális kinetikai modullal rendelkeik. A kezelés mekönnyítése érdekében elegendő megadni a tekercs fő fizikai méreteit, amiből a program kiszámítja a menet rétegeinek számát, a felhasználandó huzall hosszúságát, az ohmikus ellenállást és az induktivitást. A második modul az így kapott adatokból, valamint a beálított kapacitásértékből és feszültségértékből agy LRC szimulációt végez, ami grafikus formában is megmutatja a bekapcsolástól számított néhány milliszekundum ideig (felhasználói beállítástól függ a szimuláció időtartománya) a feszültség és áram lefutásokat a tekercsen. A harmadik nagy modul a lövedék mozgásadatait számítja és jeleníti meg. Ebben a modulban lehetőség nyílik a lövedék kezdeti sebességének megadására, így szimulálva a második, illetve harmadik fokozat kinematikáját. A szoftver fejlesztő- 


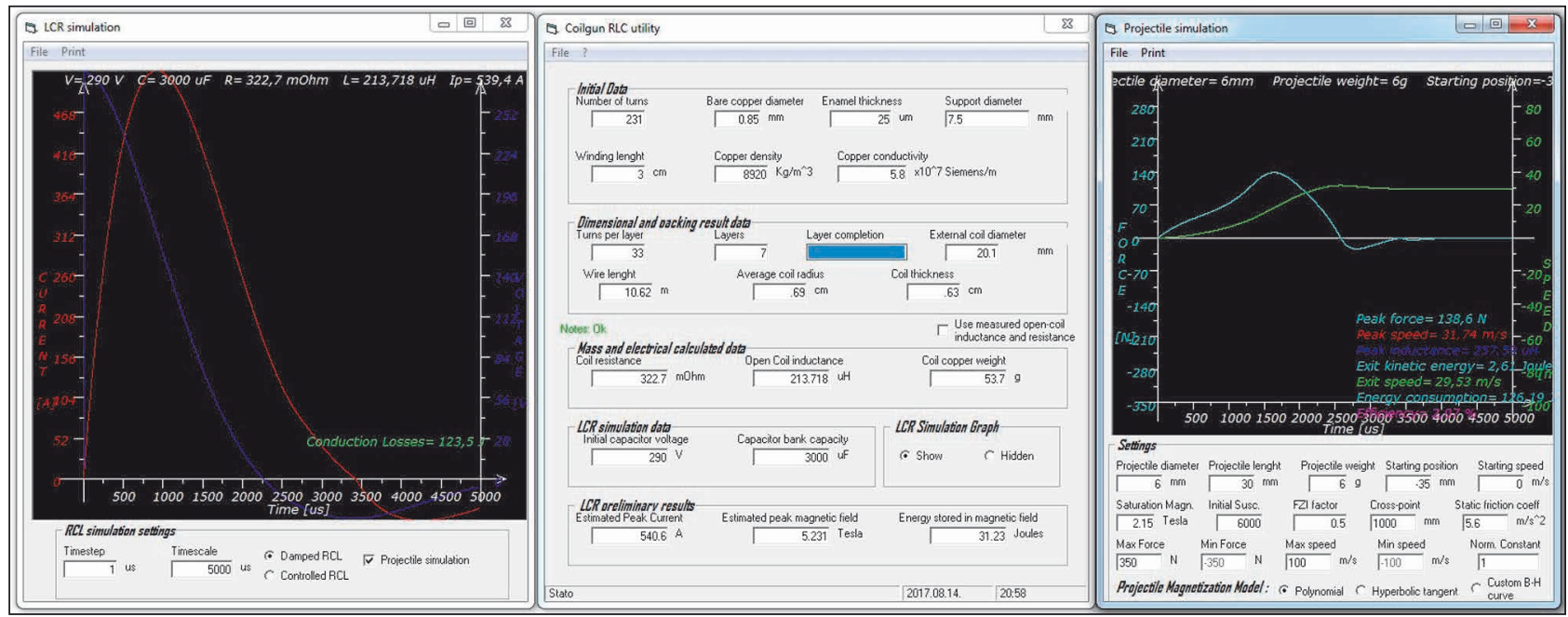

5. ábra. Az I. fokozat szimulációs eredménye

jének honlapján olvasható, hogy a szimuláció számos egyszerűsítést, illetve megkötést tartalaz. A fejlesztő tesztelései alapján a szoftver szimulációs eredményei jól közelítik a professzionális számítási modellek által adott eredményeket, így ajánlása szerint a szimulátor ugyan nem pontos, de jó segítséget nyújt egy hobbby célú elektromágneses gyorsítású fegyver megtervezése során.

$\mathrm{Az}$ 5. ábrán a tervezett első fokozat szimulációs eredményei láthatók. A fokozat kiinduló paraméterei a következők:

tekercs hosszúsága:

tekercs belső átmérője:

tekercs menetszáma:

huzal-átmérő:

kondenzátor-kapacitás:

üzemi feszültség:

lövedék hosszúsága:

lövedék átmérője:

lövedék tömege:

lövedék kezdősebessége:

$\mathrm{Az}$ 5. ábra bal oldali részletén az I. fokozat tekercsének feszültség- és áram-idő diagramja látható. A bal oldali ábrarészlet pedig többek közt a lövedék sebebességét ábrázolja az idő föggvényében. Az ábrából kiolvasható a lövedék torkolati sebessége (mivel csak egy fokozatú szimulációt végez a program). Jelen esetben ez az érték $27 \mathrm{~m} / \mathrm{s}$ körül van. Ez a sebességérték lesz az újabb szimulációnál a lövedék kezdeti sebessége.

Érdemes megemlíteni, hogy minden paraméter változatlanul hagyása esetén a gyorsító csak $0 \mathrm{~m} / \mathrm{s}$ kezdősebességü lövedék esetén biztosítja a $27 \mathrm{~m} / \mathrm{s}$ kimeneti sebességet. Amennyiben a második fokozat minden paraméterében megegyezik az elsővel, akkor a $27 \mathrm{~m} / \mathrm{s}$ sebességgel érkező lövedéket már lassítani fogja további gyorsítás helyett (6. ábra)! A 6. ábrán látható, hogy a lövedék belépő sebessége $29 \mathrm{~m} / \mathrm{s}$, a fokozatot követően pedig már csak $23 \mathrm{~m} / \mathrm{s}$ ! Ennek az az oka, hogy az I. fokozat kisülési ideje túl hoszszú, így a lövedéket a mágneses mező „visszahúzza”. Csökkenthető a kisülési idő, ha csökkentjük a fokozat kondenzátorbank kapacitásának mértékét, de akkor a kisülés során felszabaduló energia is kisebb lesz. Éppen ezért célravezetőbb a tekercs menetszámának csökkentésével csökkenteni annak induktivitását. A menetszám csökkentésének további hatása, hogy a kisülési áram nőni fog, így a fokozathoz megfelelő tirisztor kiválasztásánál erre feltétlenül figyelemmel kell lenni.

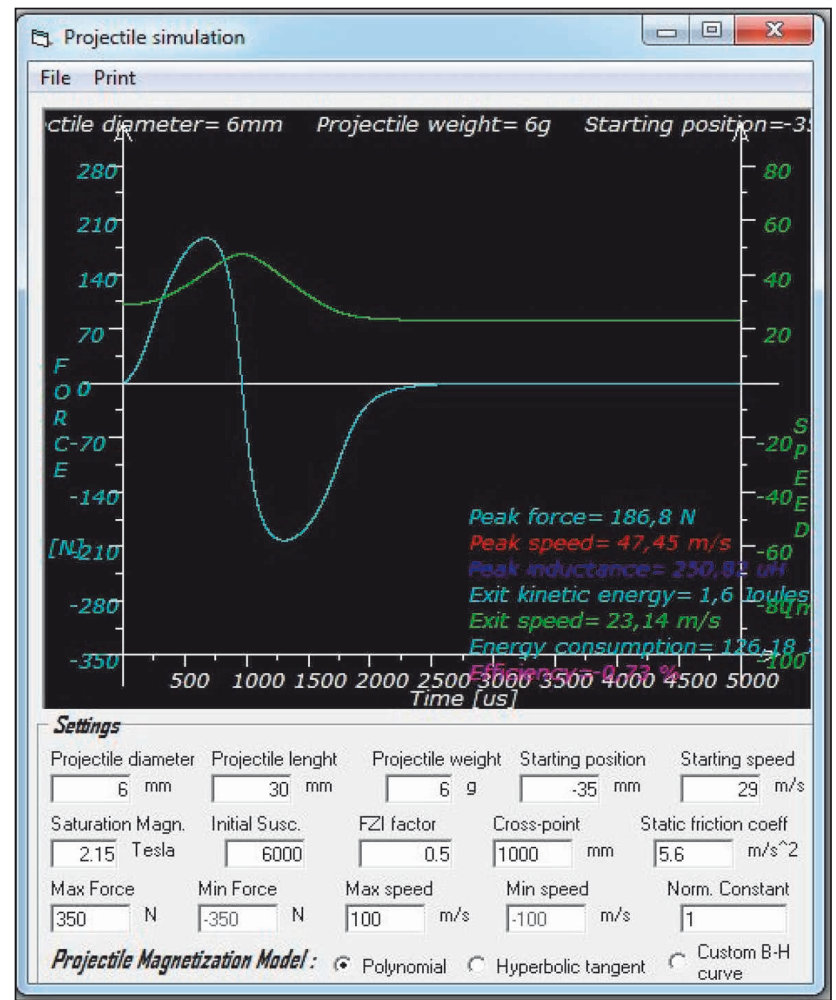

6. ábra. Az l. fokozat lassító hatása $29 \mathrm{~m} / \mathrm{s}$ belépő sebességü lövedék esetén

A 7. ábrán a II. fokozat szimulációja látható. A fokozathoz érkező lövedék sebessége az előző szimuláció kilépő sebessége. Mivel a lövedék adatai a sebesség kivételével értelemszerűen változatlanok, valamint a tekercs belső átmérője sem változik, azokat itt nem tüntettük fel. A fokozat paraméterei az alábbiak:

tekercs hosszúsága:

tekercs menetszáma:

huzal-átmérő:

kondenzátor-kapacitás:

üzemi feszültség:

lövedék kezdősebessége:

$30 \mathrm{~mm}$;

$0,85 \mathrm{~mm}$ $3000 \mu \mathrm{F}$; $290 \mathrm{~V}$; $29 \mathrm{~m} / \mathrm{s}$.

A szimulációból látható, hogy míg az első fokozat esetében a kisülési csúcsáram 540 A, a második fokozat eseté- 


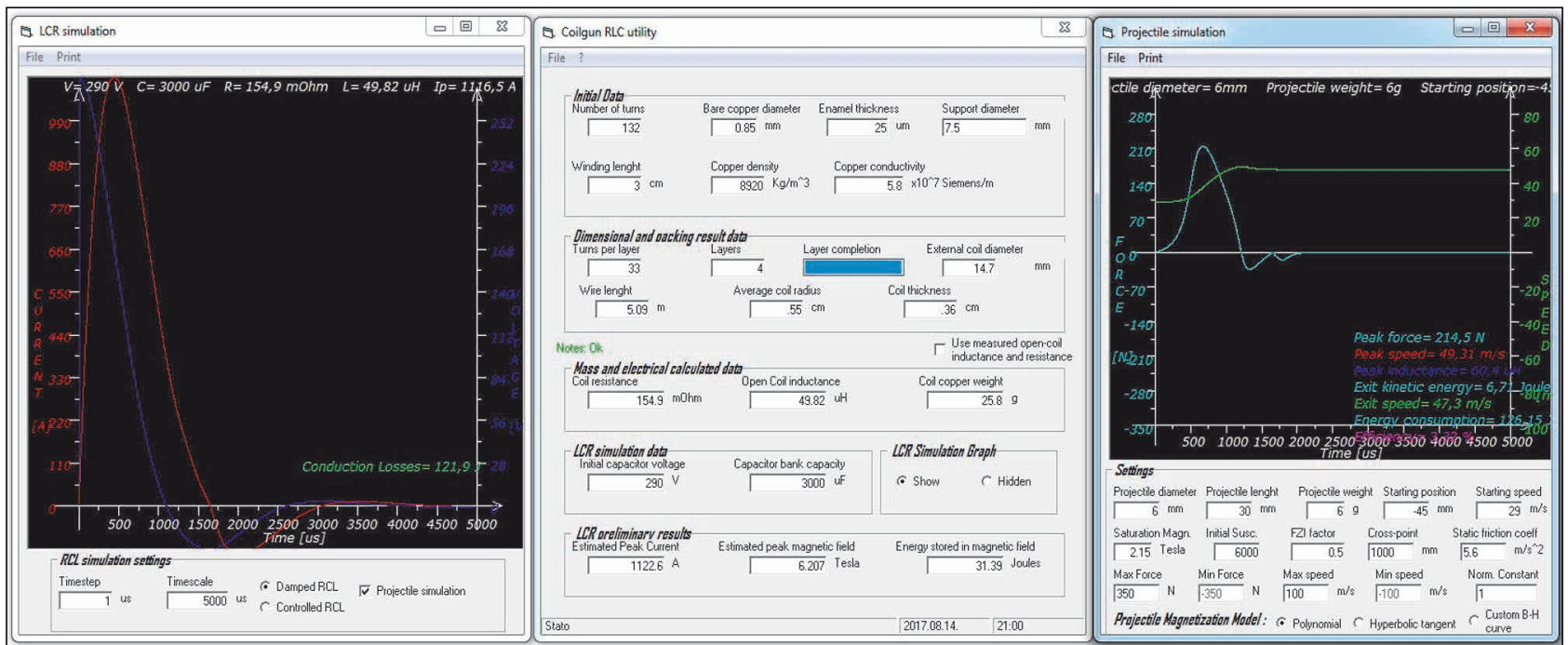

7. ábra. A II. fokozat szimulációs eredménye

ben ez már 1122 A. A lövedék sebessége a fokozatot elhagyva eléri a $47 \mathrm{~m} / \mathrm{s}$ sebességet.

A 8. ábrából kiolvasható, hogy a lövedék végsebessége több, mint $61 \mathrm{~m} / \mathrm{s}$ ami az adott lövedéktömeg esetében magasabb, mint $11 \mathrm{~J}$ torkolati energiát jelent. A III. fokozat paraméterei az alábbiak:

tekercs hosszúsága:

tekercs menetszáma:

huzal-átmérő:

kondenzátor-kapacitás:

üzemi feszültség:

lövedék kezdősebessége:

Látható, hogy a kisülési csúcsáram majdnem 1600 A!

A szimulációkkal meghatározott paraméterű szerkezet megépítéséhez egy vázszerkezetre van szükség, mivel a tekercsek és a jeladók pozícióit viszonylag pontosan tartani kell. A szimuláció során egyértelműen kiderült, hogy a gyorsító nagyon érzékeny a lövedék paramétereire, valamint a fokozatok indítási pillanata a lövedék pozíciójához képest. Mivel a mechanikai konstrukció hibája akár az eszköz működését is meghiúsíthatja, célszerű egy kellően stabil, az alkatrészek pozícióját stabilan tartó mechanikát készíteni. Kellően rugalmas, könnyen tervezhető és kivitelezhető mechanika építhető 3D-s nyomtatással. Ráadásul az eljárás kellően költséghatékony is.

\section{D MODELL KÉSZíTÉSE}

A kísérleti berendezés váza 3D-s nyomtatással készült. Az egyes alkatrészeket az OpenScad [6] nevű ingyenes 3D szerkesztőprogram segítségével terveztük. A program sajátossága az ismert CAD rendszerekkel szemben, hogy minden egyes 3D-s modellt egy leíró nyelven kell meghatározni. A 3D-s modell csak a leírás fordítását követően válik megtekinthetővé. Az egyes objektumok módosítása is csak a leíró nyelven megírt sorok szerkesztésével lehetséges. Első hallásra ez igen körülményesnek tűnik, de némi gyakorlást követően a program kényelmesen használható. Oktatástechnológiai szempontból is előnyös a program, mivel az egymáshoz illeszkedő alakzatok, valamint azok áthatásai figyelmet és rendszerszintű gondolkodást igényelnek, és fejlesztik a térbeli gondolkodás képességét. A szoftverhez szintén ingyenesen tölthető le egy angol

\section{8. ábra. A III. fokozat szimulációs eredménye}

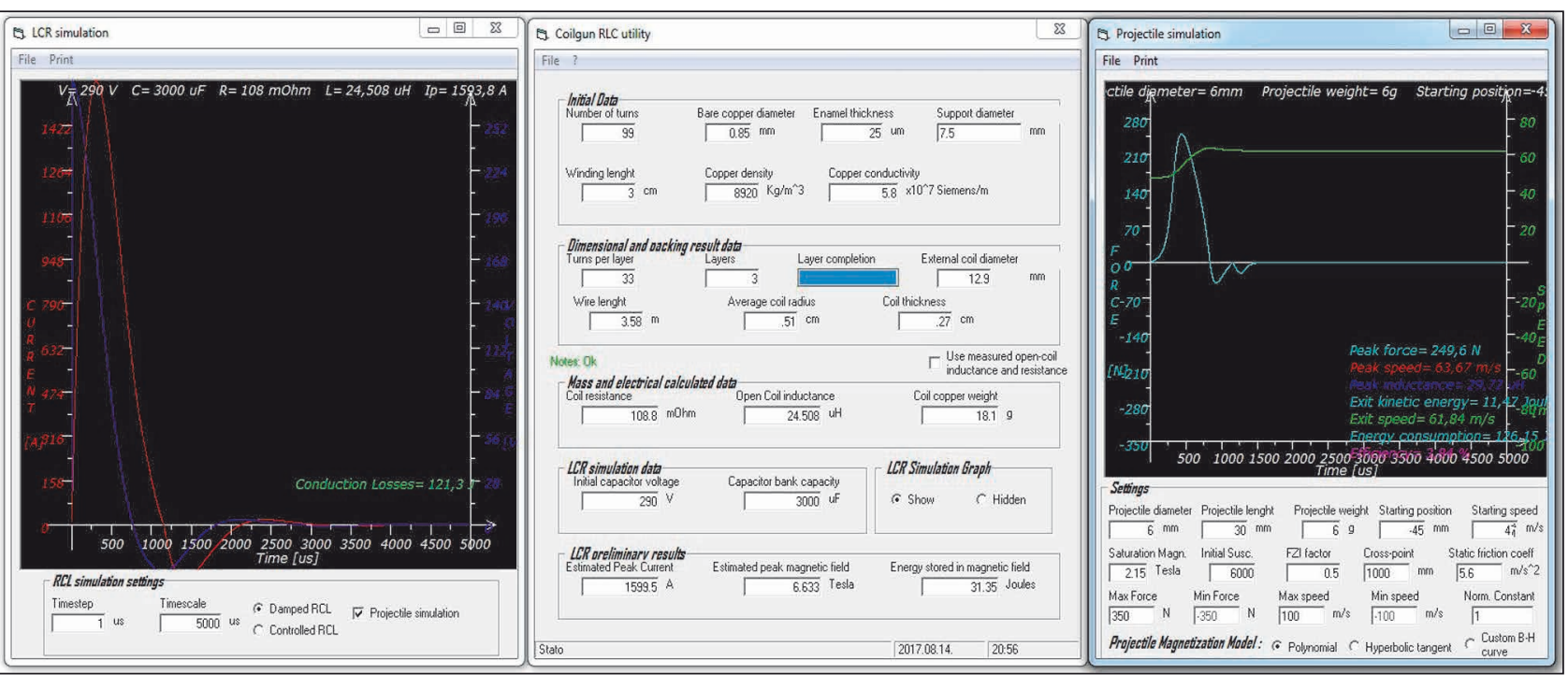




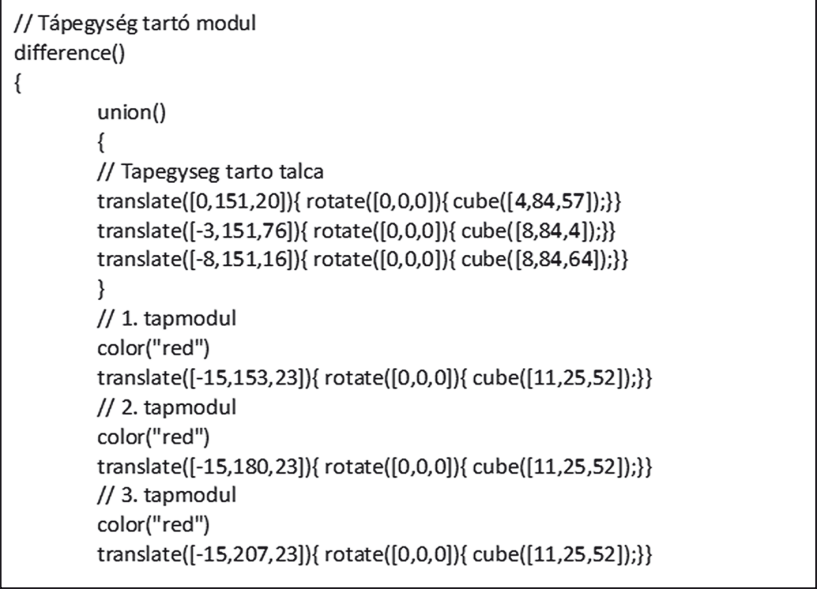

\section{9. ábra. A tápegységtartó modul OpenScad leírása}

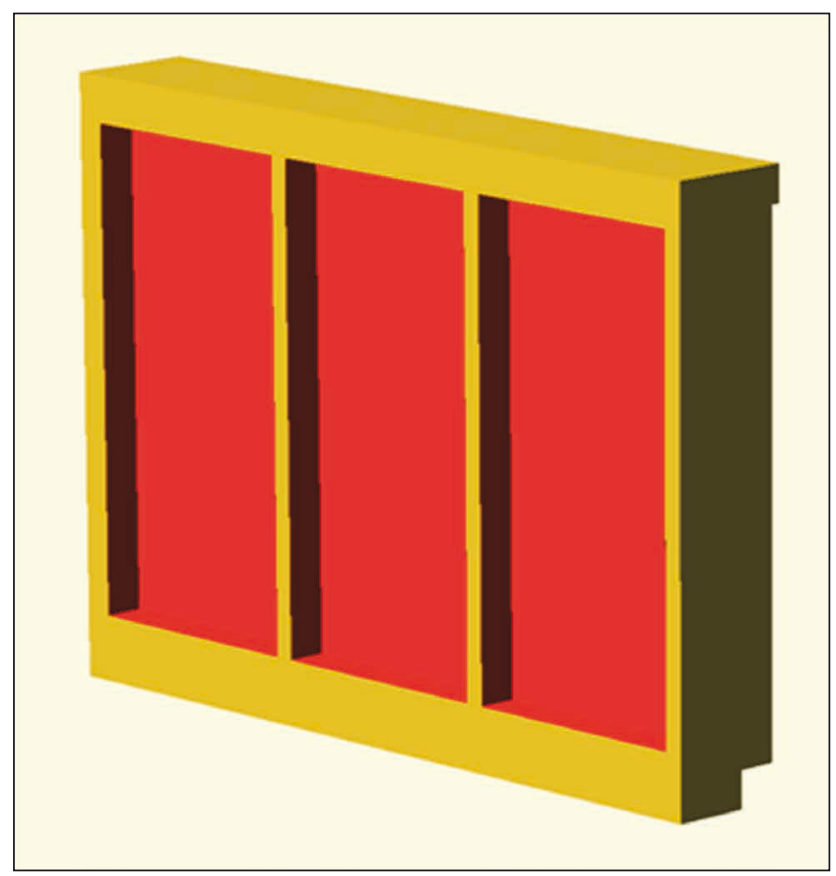

10. ábra. A fenti leírásnak megfelelő 3D modell

nyelvű felhasználói kézikönyv, ami az első lépésektől az összetett alakzatok készítéséig részletes útmutatást tartalmaz. Az OpenScad segítségével számos 3D-s illusztráció is könnyedén elkészíthető. Jelen cikk 3D-s ábrái is ezzel a programmal készültek. Az alábbiakban - a jobb érthetőség kedvéért - példaként egy egyszerü alkatrész, a nagyfeszültségű tápegységeket tartó modul leírása látható (9-10. ábrák).

A kísérleti eszköz tervezése lépésről lépésre történt. A tervezés során figyelembe kellett venni a rendelkezésre áló 3D nyomtató fizikai korlátait is, így néhány nagyobb, egy egységet alkotó elem két darabból áll össze, hogy az egyes darabok a nyomtatóval elkészíthetők legyenek. Ilyen elem például a vetőcsövet és a rajta lévő tekercseket, valamint a lövedék pozíciójának jeladóit tartó egység. A hoszsza miatt a rendelkezésre álló nyomtató nem képes kinyomtatni, így két darabra kellet bontani (11. ábra). Természetesen ilyen esetekben a két összeillő darabot pozicionáló elemekkel célszerű ellátni. A 11. ábrán, a kisebbik alkatrész oldalán látható négy zsákfurat is amelyek az imént említett pozicionálást hivatottak elősegíteni.

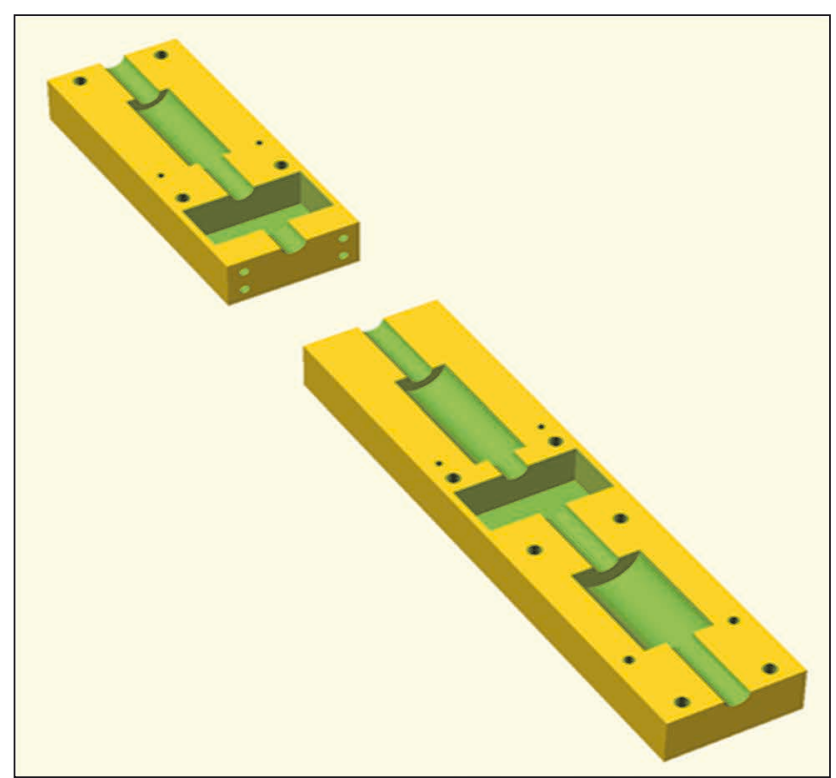

11. ábra. A két darabból álló vetőcsőtartó egység 3D-s modellje

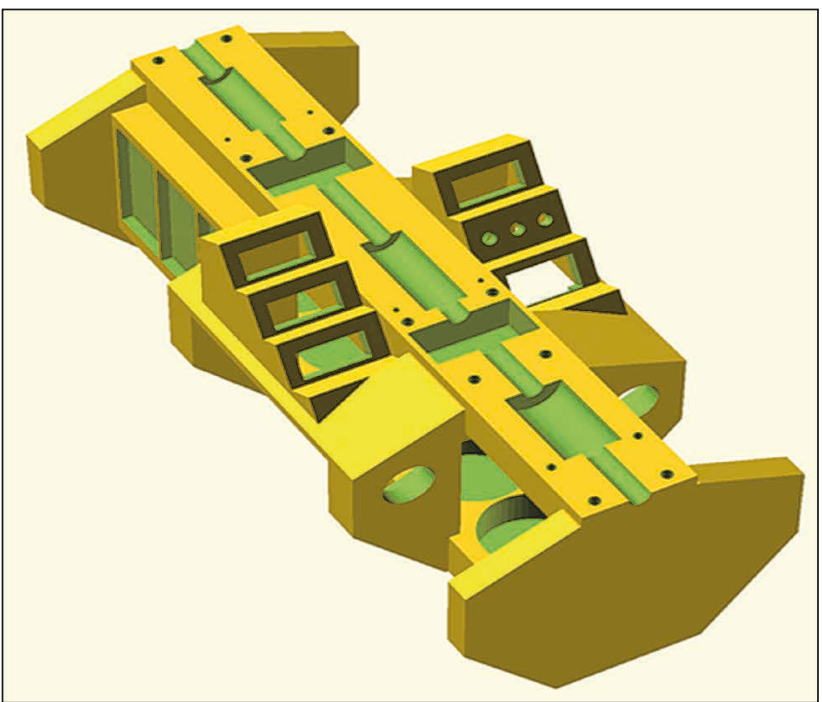

12. ábra. Az elektromágneses gyorsító vázszerkezetének 3D-s modellje

A tervező program jó lehetőséget biztosít az egyes alkotóelemek illeszkedésének megtervezésére is. Az egyes elemek közösen is megjeleníthetők, így jól ellenőrizhető azok egymáshoz illesztettsége, vagy esetleg annak hiányossága. A 12. ábrán a komplett vázszerkezet látható.

Mivel a vázszerkezet számos alkatrész befogadását kell, hogy biztosítsa, a tervezés során elkészültek ezen alkatrészek stilizált modelljei is. Ilyenek például a kondenzátorok, kapcsolók, műszerek vagy a tirisztorok. A részegységek illesztettségének ellenőrzéséhez hasonlóan, a program lehetőséget biztosít a beépítésre kerülő alkatrészek elhelyezésének ellenőrzésére is. A jobb áttekinthetőség érdekében az egyes alkatrészek színezhetők is (13. ábra).

\section{KísÉRLETI MÉRÉSEK, TAPASZTALATOK}

Az elkészült eszközön méréseket végeztünk annak érdekében, hogy megvizsgáljuk a szimulációban előre jelzett ered- 


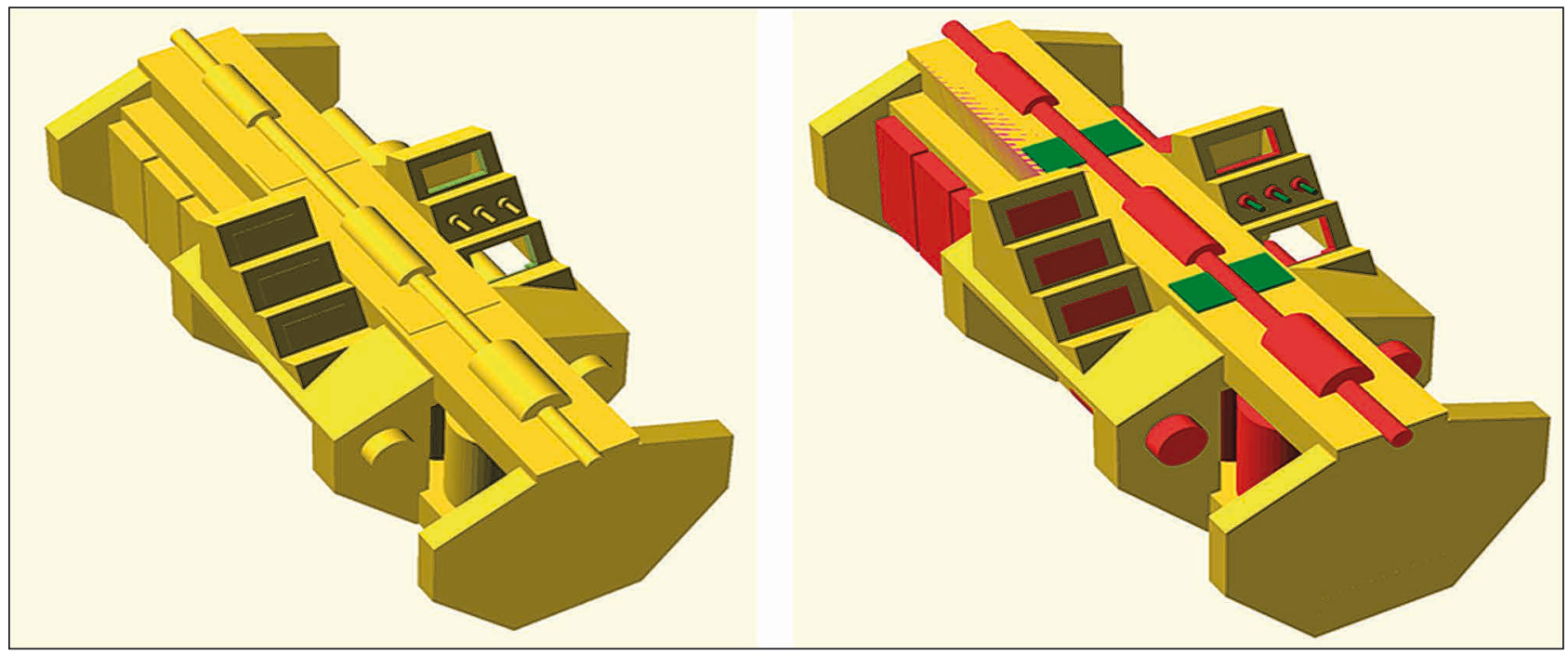

13. ábra. Az elektromágneses gyorsító vázszerkezetének, és az abban található eszközök virtuálisan összeszerelt 3D-s modellje egyszínú (bal oldal) és színezett (jobb oldal) változatban

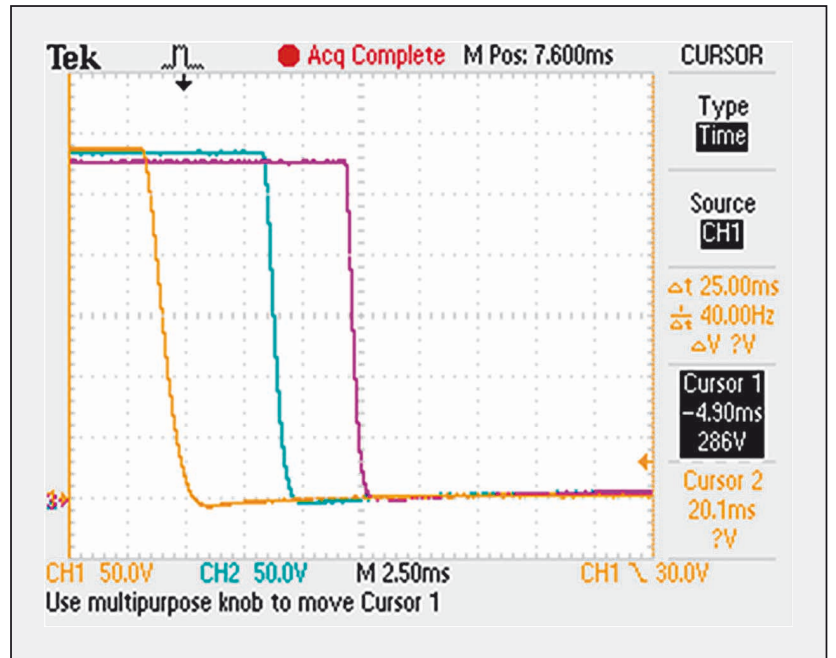

14. ábra. Az egyes fokozatok együttes feszültség-idő oszcillogramja egy lövés alkalmával

mények, illetve a tekercseken mért időbeni változások jellegei korrelálnak-e egymással. Első lépésben megvizsgáltuk, hogy a valós lövést követően a tekercsek feszültségeinek időbeni lefutása megfelel-e az előzetes elvárásoknak. A méréseket tárolós, több csatornás digitális oszcilloszkóppal végezve, a 14. ábra szerinti oszcillogramot kaptuk. Az ábrán látható kezdeti egyenfeszültségek minimális eltérései az egyes tekercseken a különálló töltő áramkörök kissé eltérő beállításai okán tapasztalhatók. Jól látható, hogy a lefutási meredekségek az egyre gyorsuló lövedéknek megfelelően - ahogy az az elméleti előrejelzés szerint is kívánatos volt - egyre nagyobbak, azaz a kisülési idők egyre rövidebbek lettek (15. ábra).

A kinetikus mérések eredményeit az 1. és a 2. táblázatok szemléltetik. Az első vizsgálatok arra irányultak, hogy az egyes fokozatok valóban tovább gyorsítják-e a lövedéket. Nem megfelelő beállítások esetén ugyanis gyakran előfordul, hogy a további fokozatok rossz időzítés okán visszarántják az előző fokozat által felgyorsított lövedéket és vég-

15. ábra. Az egyes fokozatok feszültség-idő oszcillogramja egy lövés alkalmával

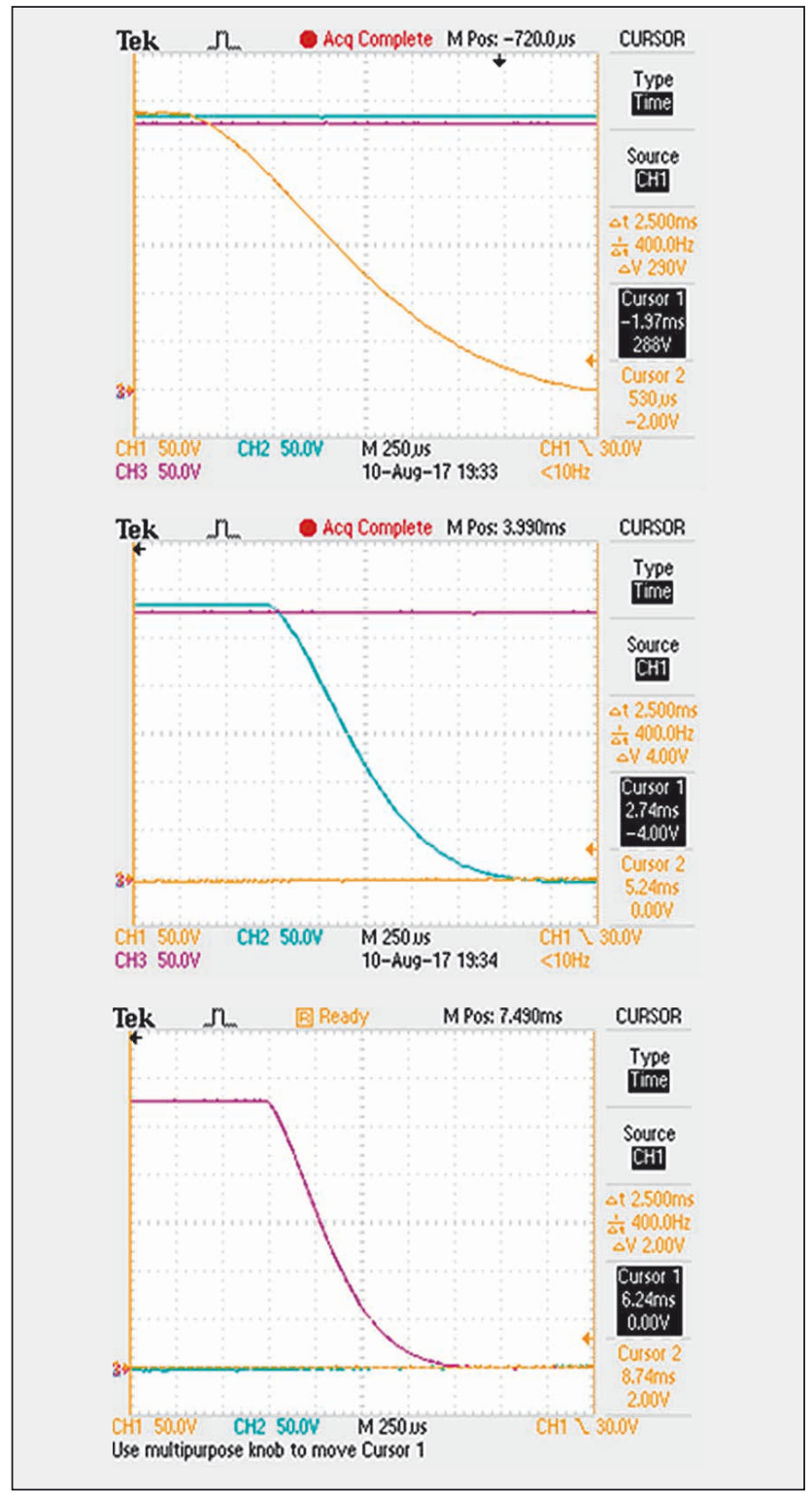


1. táblázat. A torkolati energia alakulása a gyorsító fokozatok függvényében

\begin{tabular}{|c|c|c|c|}
\hline & I. fokozat & I. + II. fokozat & I. + II. + III. fokozat \\
\hline 1. mérés torkolati sebesség $[\mathrm{m} / \mathrm{s}]$ & 23,39 & 34,2 & 39,3 \\
\hline 2. mérés torkolati sebesség [m/s] & 23,51 & 33,9 & 39,6 \\
\hline 3. mérés torkolati sebesség [m/s] & 22,28 & 35,2 & 38,4 \\
\hline Átlag torkolati sebesség [m/s] & 23,06 & 34,43 & 39,1 \\
\hline Átlagos torkolati energia [J] & $\sim 1,6$ & $\sim 3,5$ & $\sim 4,6$ \\
\hline
\end{tabular}

2. táblázat. A torkolati energia alakulása a lövedék tömege és kezdő pozíciójának függvényében

\begin{tabular}{|c|c|c|c|c|}
\hline & \multicolumn{2}{|c|}{6 gramm lövedék } & \multicolumn{2}{|c|}{5 gramm lövedék } \\
\hline & $\begin{array}{c}0 \text { mm kezdő } \\
\text { pozíció }\end{array}$ & $\begin{array}{l}-2 \text { mm kezdö } \\
\text { pozíció }\end{array}$ & $\begin{array}{c}0 \text { mm kezdö } \\
\text { pozíció }\end{array}$ & $\begin{array}{l}-2 \text { mm kezdő } \\
\text { pozíció }\end{array}$ \\
\hline $\begin{array}{l}\text { 1. mérés } \\
\text { torkolati sebesség [m/s] }\end{array}$ & 39,3 & 47,0 & 48,2 & 52,5 \\
\hline $\begin{array}{l}\text { 2. mérés } \\
\text { torkolati sebesség }[\mathrm{m} / \mathrm{s}]\end{array}$ & 39,6 & 45,4 & 48,4 & 52,4 \\
\hline $\begin{array}{l}\text { 3. mérés } \\
\text { torkolati sebesség [m/s] }\end{array}$ & 38,4 & 45,5 & 48,5 & 52,4 \\
\hline $\begin{array}{l}\text { Átlag } \\
\text { torkolati sebesség [m/s] }\end{array}$ & 39,1 & 45,96 & 48,36 & 52,43 \\
\hline Átlagos torkolati energia [J] & $\sim 4,6$ & $\sim 6,3$ & $\sim 5,8$ & 6,8 \\
\hline
\end{tabular}

eredményül a több fokozatú eszköz gyengébb, mint a csupán egy fokozatból álló gyorsító. Az 1. táblázat az egyes fokozatok hatását szemlélteti. Jól látható, hogy mind a második, mind a harmadik fokozat növeli a lövedék sebességét. A kísérlet során, a három fokozat együttesen $4,5 \mathrm{~J}$ torkolati energiát eredményezett, ami elmaradt a szimulációs eredményektől ( $11 \mathrm{~J}$ körüli érték). Ennek oka több forrásból származhat. Részben a tekercsek nem pontos kivitelezése, nagyobb részben a tekercsek indításának időzítése okozza az eltérést.

Mivel a teljesítmény szempontjából kritikus a lövedék kezdeti pozíciója, így méréseket végeztünk annak változtatásával. A 2. táblázat, mindhárom gyorsítótekercs használata mellett, a kezdeti pozíció és a felhasznált lövedék tömegének hatását szemlélteti.

\section{6. ábra. Az elkészült eszköz fényképe}

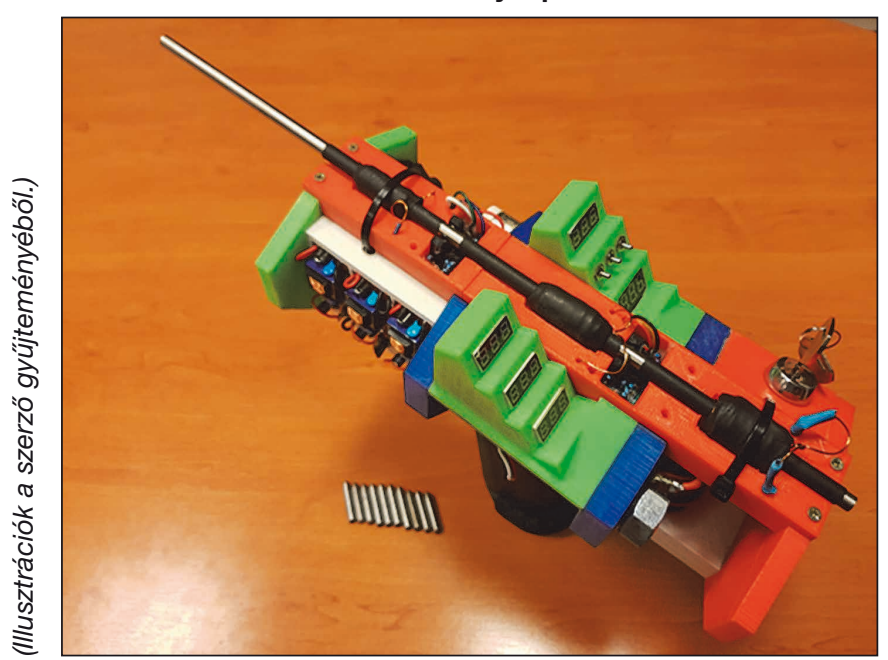

A lövedék tömegének csökkentése nagyobb torkolati energiát eredményezett, ami a gyorsítás hatásfokának javulása miatt történt. Ugyanazon lövedék kissé beljebb tolva a vetőcsőbe, jelentős többlet energiára tett szert a cső végéhez illesztett lövedékhez képest. Több kísérlet során a 2 mm-rel a cső végétől beljebb helyezett lövedékek torkolati energiája bizonyult a legnagyobbnak. Így az 5 gramm tömegű lövedékkel sikerült 6,8 J torkolati energiát elérni, ami még mindig jelentősen elmarad az elméleti számított értéktől.

Mivel a tekercsek indítási ideje a lövedék helyzetéhez képest kritikus, az elméleti energiaszintet valószínúleg a II. és III. fokozatok időzítésével lehetne megközelíteni. A berendezés azonban nem alkalmas ezen fokozatok álítására, így egy újabb kísérleti berendezés építése szükséges a maximális torkolati energia eléréséhez.

\section{FORRÁsOK}

[1] Burgess, T.J. et al.: The Electromagnetic Theta Gun and Tubular Projectiles. In: IEEE Transactions on Magnetics, 1982. vol.18 no.1, p. 46-59. DOI:10.1109/ TMAG.1982.1061811;

[2] Andrews, J. A. - Devine, J. R.: Armature Design for Coaxial Induction Launchers. In: IEEE Transactions on Magnetics, 1991. vol. 27 no.1, p. 639-643. DOI: 10.1109/20.101109;

[3] Coilgun Systems. http://www.coilgun.eclipse.co.uk/ [2018.04.16.];

[4] Barry's Coilgun Design Site. https://www.coilgun.info/ [2018.04.16.];

[5] Coilgun simulator. http://www.webalice.it/saverio. filippi/coilgun_simulator.html [2018.04.16.];

[6] https://en.wikibooks.org/w/index. php?title=OpenSCA...2. 